\title{
The Similarities and Differences of Hang Tuah and Cindua Mato Characters
}

\author{
Suhardi ${ }^{1}, \&$ Thahirah ${ }^{2}$ \\ Universitas Maritim Raja Ali Haji ${ }^{1}$; Pascasarjana UIN Suska Riau ${ }^{2}$ \\ suhardi@umrah.ac.id; afifahthahirahh@gmail.com
}

\begin{abstract}
How to cite (in APA Style): Suhardi, \& Thahirah. (2019). The Similarities and Differences of Hang Tuah and Cindua Mato Characters. Jurnal Pendidikan Bahasa dan Sastra, 19(1), 123-130, doi: 10.17509/bs_jpbsp.v19i1.20764
\end{abstract}

Article History: Received (11 March 2019); Revised (28 March 2019); Accepted (1 April 2019).

Journal homepage: http://ejournal.upi.edu./index.php/BS_JPBSP

\begin{abstract}
The Malay and Minangkabau people are those who like to speech and act on literature. This can be seen through the existence of several genres of literary works from those ethnic, ranging from the form of saga, tale, and legend. Among them are Hang Tuah and Cindua Mato saga. Hang Tuah saga grew and developed in Malay society, while Cindua Mato saga grew and developed in Minangkabau society. Both sagasare interesting to be studied as an analytical study. First, Hang Tuah and Cindua Mato saga is a great literary work owned by both ethnic groups. As a masterpiece, they both have an appeal to be analyzed in many ways. Secondly, Hang Tuah and Cindua Mato figures by both ethnic communities have become a big myth. Hang Tuah became myth by the Malay community as a brave and loyal figure to the king. So did with the figure of Cindua Mato who became myth by Minangkabau society as a brave and loyal figure to the king. As with other literary works, Hang Tuah and Cindua Mato saga contains the aesthetic, moral, and cultural elements of their owners. It is as stated by Taum that oral literature has an aesthetic effect and moral context as well as a particular society culture. This research analyzed and examined the cultural similarities and differences (characters) in Hang Tuah and Cindua Mato saga. This study is expected to produce the same perception of both sagas. Likewise, the possibility of a kinship element exists between ethnic Malay and Minangkabau.
\end{abstract}

Keywords: similarities; differences; Hang Tuah; Cindua Mato

\section{Persamaan dan Perbedaan Karakter Hang Tuah dan Cindua Mato}

\begin{abstract}
Abstrak: Orang Melayu dan Minangkabau adalah mereka yang suka bertindak tutur dalam sastra. Hal ini terlihat dari keberadaan beberapa jenis karya sastra dari suku tersebut, mulai dari bentuk hikayat, dongeng, dan legenda. Di antaranya adalah kisah Hang Tuah dan Cindua Mato. Kisah Hang Tuah tumbuh dan berkembang di masyarakat Melayu, sedangkan kisah Cindua Mato tumbuh dan berkembang di masyarakat Minangkabau. Keduanya sagas menarik untuk dipelajari sebagai studi analitik. Pertama, Hang Tuah dan Cindua Mato saga adalah karya sastra hebat yang dimiliki oleh kedua kelompok etnis. Sebagai mahakarya, keduanya memiliki daya tarik untuk dianalisis dalam banyak hal. Kedua, tokoh Hang Tuah dan Cindua Mato oleh kedua komunitas etnis telah menjadi mitos besar. Hang Tuah menjadi mitos oleh komunitas Melayu sebagai sosok yang berani dan setia kepada raja. Begitu pula dengan sosok Cindua Mato yang menjadi mitos oleh masyarakat Minangkabau sebagai sosok yang berani dan setia kepada raja. Seperti karya sastra lainnya, kisah Hang Tuah dan Cindua Mato berisi unsur-unsur estetika, moral, dan budaya dari pemiliknya. Sebagaimana dinyatakan oleh Taum bahwa sastra lisan memiliki efek estetika dan konteks moral serta budaya masyarakat tertentu. Penelitian ini menganalisis dan memeriksa persamaan dan perbedaan budaya (karakter) dalam kisah Hang Tuah dan Cindua Mato. Penelitian ini diharapkan menghasilkan persepsi yang sama dari kedua kisah tersebut. Demikian juga, kemungkinan elemen kekerabatan ada antara etnis Melayu dan Minangkabau
\end{abstract}

Kata kunci: persamaan; perbedaan; Hang Tuah; Cindua Mato 


\section{INTRODUCTION}

The Malay and Minangkabau people have been known as a talking and literary society for a long time. It happens no other, according to Endraswara (2011,p.152) because man is a homo fabulans, who love to speak and literature. From the habit of speaking and literature then born some forms of literary genre (oral), ranging from the form of saga, tale, until the legend. As the name implies, literature is a literary type delivered by the owner by the way spoken. According to Fang (2011,p.1-2), "Oral literature is a literature that is delivered by way of spoken". Oral literature is a work that is spread from mouth to mouth hereditary (Endraswara, 2002, p.151). It also happened to Hang Tuah and Cindua Mato saga which its delivery system was done by word of mouth. In addition, by using subtle and meaningful languages (Eagleton (1988: 4), they are also passed down from generation to generation, having an aesthetic and moral context, as well as the cultural effects of society (Taum, 2011, p.21 According to Teeuw (1984, p.120), Aristotle has laid a firm foundation on the view that literary works as autonomous structures.

Among the oral literature living in the midst of ethnic Malay and Minangkabau are Hang Tuah and Cindua Mato saga. Both sagasare very popular in the middle of society. Its popularity is because both have a subtle language and solid meaning. Bothsagasare also rich of cultural values. Both sagasare interesting to be studied as an analytical study. First, Hang Tuah and Cindua Mato saga is a great literary work owned by both ethnic groups. As a masterpiece, they both have an appeal to be analyzed in many ways. Secondly, Hang Tuah and Cindua Mato figures by the two ethnic communities have become a big myth. Hang Tuah storied by the Malay community as a brave and loyal figure to the king. Also with Cindua Mato figure who by Minangkabau society believe as a brave and loyal figure to the king. As a great literary works,both of the stories are also interesting to be seen more closely about the similarities and differences that they have. Especially the similarities and differences of characters contained in both saga. This study'sresult will certainly in the same perception of both saga and kinship owned between ethnic Malays and Minangkabau.

Through the study of both sagas, its expected can exposed the wealth of thought, owned traditions, and forms of lifestyle belonged to both communities. It is as mentioned by Zaimar (1990, p.1) that literary works shows thoughts, life, and traditions that live in a society. Therefore, by studying a literary, as well as examine the thoughts, traditions, and lifestyle of a community owner. Thus, to know the mindset, life, and traditions of Malay and Minangkabau people, the study can be conduct and analyzed the forms of literary works owned and exist by both ethnic groups. One of them is conducting studies and analysis on Hang Tuah (Malay) and Cindua Mato (Minangkabau). Hang Tuah and Cindua Mato sagasare a very popular story in Malay society. Likewise Cindua Mato saga is a very popular saga in Minangkabau society. Even the Cindua Mato saga by the Minangkabau people has a high historical value, especially with regard to the Minangkabau Empire in the past. Both are great literary creations and have a very important position in the history of the development of the Indonesian literary world, especially the old prose. The results of the study will certainly strengthen the social and cultural relations between the Malay and Minangkabau communities. They can more coexist and uneasy to be broken down by other ethnicity.

There are several theories that can be used as the basis of the second study of saga, such as through the use of structuralism theory, intertectuality, and theory of literary receptions. According to the theory of structuralism, literary works are assumed to be phenomena that have structures which interconnected with one another (Endraswara, 2011, p.49). Literature is a process of communication, the process of dialogue between the author and the reader on a continuous basis (Seger, 2000, p.30). Literary work is a system consisting of 
interrelated elements in forming a totality (Esten, 1999, p.11-12). Thus, as a system, literary works can be seen as a complete and a broad system (Scholes, 1974, p.10). Structural analysis can unravel all aspects of existing literary works to obtain the meaning of the whole work (Teeuw, 1984, p.135). Structural studies of literary works have actually been done by Levi-Strauss. The model of this study in Indonesia has also been conducted Ahimsa-Putra (2006) against the tales that exist in the archipelago.

According to the theory of intertectuality, literature is a comparative study of literary creation. Frow (1990, p.45) states that the study of literary intertectuality is the study of the process of understanding the literary text of the content aspect, the differences possessed, and from the historical aspect of the text itself. According to Julia Kristeva in Endraswara (2011, p.131), the existed of the theory of intertectuality because of the influence of the nature of the text in which it contains other texts. Meanwhile, according to Culler (1981.p103) the study of intertectuality has led the researcher to the view that the predecessor text is a code that allows its significant effect of various meanings. Barthes (1981, p.31-32) states that the study of intertectuality not only gives a different meaning but also creates a new meaning. By doing intertectual studies on the text Hang Tuah and Cindua Mato it will generate a new understanding of both text. Wolfgang Iser in Holub (1984, p.83) states that the result of the process of interaction between the text with the reader is a meaning. According to Riffateree (1978, p.1) literary phenomena is a dialectic phenomenon between text and reader. In understanding the literary texts, a reader must understand well with regard to language codes, literary conventions, and cultural conventions (Teeuw, 1991, p.12). The creation of a literary work is not assumed to be in avacuum cultural environment. A text will "stand side by side" with other texts to bring effect to its understanding (Nurgiyantoro and Anwar, 2017).
The study of literary receptions is a study that sees more literary relationships with readers. According to Juss in Endawara (2011, p.123), literary works are not the monuments which tell meaning. The literary work is like an orchestra, always giving the reader the opportunity to present a new resonance.

According to Bakhtin (1986, p.104107) that in a literary work there is a dialogue between inner texts (such as aesthetics, imagination, and illusion) and the external text of the author's experiences, such as ideology, history, morals, and culture. Pradopo (1995) states that every literary works have some sort of the attachment of history together with the following attachment In addition, Ratna (2003) believes that words are the intersection of textual impression, dialogue between writers and readers, respondents, characters, and socio-cultural context. Its literary structure is always seen as connected to other structures and always reads the help from other texts. The idea of intertextuality is to incorporate text into its socio-historical context.

This research compares two texts: Hang Tuah text and Cindua Mato text. The method used in this intertextual analysis is the same as used by Junus (1999) and Aveling (2012), which is analyzing the intertextual by comparing the two texts and describing the results of a new interpretation of the two texts.

Esten (1999) has analyzed the text of Cindua Mato's play and Kaba Cindua Mato's text. The results obtained are various editions of Cindua Mato text is a traditional understanding of Cindua Mato. Wisran Hadi's Cindua Mato play is a new understanding of Cindua Mato's myth.

Fikyindra (2015) obtained the data that Hang Tuah characters are; a) brave, wise, clever, religious, and obedient. The plot in Hang Tuah saga Volume 1 by Muhammad Haji Saleh includes situation, generating, circumstances, climax, denouement. With backgrounds: (a) Place background, (b) Timeframe, (c) Background atmosphere, (d) Social background. The values are divided into three values: (a) 
Religious value, (b) Social value, and (c) Individual value.

Yullia (2014) has also obtained the data that Hang Tuah saga as hypogram and Admiral Hang Tuah tale as a new work (transformation) as follows. The story of Hang Tuah saga has more characters and characterizations, plot, background of time, different theme with Admiral Hang Tuah tale. Hang Tuah saga started the story with a kingdom from the land of heaven while Admiral Hang Tuah tale directly told about Hang Tuah. So when reading Hang Tuah saga the reader feels carried on the story of ancient times, different when reading Admiral Hang Tuah tale readers only know the story simply like that and ended happily. Hang Tuah saga has historical elements. Admiral Hang Tuah tale ends happily, proving that Admiral Hang Tuah tale serves as a consolation story for the Minangkabau community. In the preface of Admiral Hang Tuah tale it is said that this tale originated from Melaka until became a tale in Minangkabau. From this research it is advisable to develop research on Admiral Hang Tuah tale and Hang Tuah saga that may not yet be revealed.

Wulandari (2016) said that the results of her research were (1) Minang women in Cindua Mato tale showed the image of Minang women of ancient times that were identical with adherence to custom and understood his position as a Minang woman. In the novel Memang Jodoh, the portraitof Minang women focuses more on cases or unfair treatment because the minds of people or leaders of certain people who do not lead to custom should be referred. (2) The comparison of Minang women in Cindua Mato tale and the novel Memang Jodoh with Minangakabau culture has provided some important notes, that Minang women have some prominent positions both for unmarried and married woman.

Ruaidah (2017) explained in her research article entitled "Feminism Ideology in Cindua Mato Tale" that Cinduo Mato Tale representing the role of Minangkabau women. Bundo kanduang has an imaged as a kind woman who is gentle, authoritative, and has the ideology of power as a leader in a wide area. For Minangkabau, the position of women has a special position in the house as well as in custom.

\section{METHOD}

The research method used in this study is the method of content analysis, which provides an interpretation, understanding, of the observed object (Ratna, 2011, p.44). in this case hikayat Hang Tuah and Cindua Mato. The content analysis method, almost the same as the descriptive method. According to Ghony and Almanshur, (2012, p.89), the method of descriptive aims to describe and analyze the phenomena, events, social activities, attitudes, beliefs, perceptions, and thoughts of individuals as well as in groups. The content analysis method was used in the second comparative study of the saga intended to find out the similarities and differences that Hikayat Hang Tuah and Cindua Mato had as a great saga owned by Malay and Minangkabau communities.

\section{RESULTS AND DISCUSSION}

Analysis and interpretation of the similarities and differences between hang Tuah saga and Cindua Mato can be done from the aspects of structural theory, intertectuality, and theory of literary resepsion. Especially regard with aspects of themes, characters, character traits (characters), and cultural values.

From the aspect of the theme, Hang Tuah saga and Cindua Mato have in common, it is equally raised the element of slander as the element that builds the story. Hang Tuah several times gets slander committed by the palace soldier named Patih Kerma Wijaya so Hang Tuah must leave the king's palace for several times and hide away in exile. The first Hang Tuahhideaway is he was slandered by doing something bad to the court ladies so that he must hide into the Indrapura area. The second biding, he gets slander to have done something bad with the consort of the two kings so he must hide upstream of the Malacca River. Also 
because ofImbang Jayo's slandered against Dang Tuanku (Bundo Kanduang's son), so that Bundo Kanduang and his son (Dang Tuanku) get embarrassed, with the annulment of Dang Tuanku's engagement with Puti Bungsu. Likewise with the fake news spread by Imbang Jayo to the public that Dang Tuanku has an incurable disease so that Puti Bungsu's father feared his daughter would be a single. Hang Tuah's character must concede of his feelings because Tun Teja finally married by the king as his second consort. Likewise with Dang Tuanku who disappointed because her lover named Puti Bungsu will be married by Imbang Jayo. In the end Imbang Jayo also disappointed because the candidate of her lover, Puti Bungsu, finally married Dang Tuanku.

From the aspect of characte-rization (character and figures), Hang Tuah character for the Malay society is certainly not strange anymore because it has become a hereditary myth as a magic (mantraguna) figure. The figure of a knight who has been proved for his success.Also with the figure Cindua Mato, for Minangkabau community is not a stranger anymore because it is known as a knight figure whose success was very extraordinary. The prosperity of Hang Tuah's characters as well as his friends (Hang Jebat, Hang Lekiu, and Hang Kesturi) quells the pirates (Lanun) in the South China Sea which always disruptingthe merchant ships. The next treasure is his success in securing the king's palace environment from riots. The next success is able to subdue his own friend who also has the same virtue, namely Hang Jebat. In Cindua Mato saga also, Cindua Mato character succeeded in winning the resistance by the thieves on Tambun Tulang Hill until they declared themselves to be the loyal followers of Cindua Mato. Likewise, Cindua Mato finally succeeded in killing the character of Tiang Bungkuk which had been difficult to subjugate.

From the aspect of character, the hang Tuah and Cindua Mato characters have the same character, which is always faithful devoted themselves to the king. Although he hasgot some pressures several times from the king, his love to the nation and the country is very high, against anything else. When he was asked to return to the palace by the king from his hiding in Indrapura, he states wholeheartedly ready to return to devote himself to the king. Similarly, when he was summoned by the king to the palace from his hideout in the Malacca River, he happily expressed his readiness to devote himself back to the king. This attitude is only inside of someone who really has a sense of love to the country and nation above love to himself. Also with the figure of Cindua Mato, who is ready to sacrifice himself to go to the Ngiang River in the area of Si Kalawi to attend the feast of Puti Bungsu.TambunTulang Hill had been so feared by the traders because it is famous for its sadistic robbers he faced earnestly. He did not think anymore how the life of his wife later if he died. Likewise, when facing the father of Imbang Jayo who is very famous with hismagic, there is no fear in his. There is only one determination for him, which can give something best to the king and uphold justice and truth on this earth. Hang Tuah and Cindua Mato turned out to be two characters that have the same character, which has the same high servant of the king.

From the aspect of social values, Hang Tuah and Cindua Mato figures are equally able to socialize well in the midst of their society. Both are the figures who always uphold the values of society so that its presence in the middle of society is very acceptable. People will feel very lost when this character is not present in their midst. Hang Tuah is a sadistic character in front of his opponents because if doing things that harm the society, then does not hesitate to be dealing directly with him. Hedares to kill if he thinks endangering the community. Just look what Hang Tuah did to the pirates (Lanun) in the South China Sea (killed). Likewise the riots that do the commotion in front of the king's palace. Hang Tuah figure is feared by his opponents. The same thing is in the figure of Cindua Mato. His successes to crush the leader of robbers 
(Imbang Jayo's men) on Tambun Tulang Hill causes the robbers bending their knees and declare ready to devote themselves to Cindua Mato. The same thing happened when Cindua Mato successfully killed Tiang Bukuk. The subordinates of Bow Slow declared ready to devote themselves to Cindua Mato. Cindua Mato was finally appointed the king in the Ngiang River and in $\mathrm{Si}$ Kalawi area. During his reign, the people lived safely and peacefully.

From the aspect of cultural values, especially the cultural values of Malay and Minangkabau. Malay cultural values as embodied in Gurindam Dua Belas written by the Malay master's writer, Raja Ali Haji. Also with the cultural values of Minangkabau, as embodied in custom petatah-petitih which became the basis of Minangkabau people daily life. Malay cultural values as embodied in Raja Ampat's Gurindam Dua Belas works including the values of religious, belief, social, moral, ethical, and leadership. Those values are the evident of his life in the midst of society. Similarlywith the figure of Cindua Mato whoalways upholds the custom values in his various forms of activities. Whether speaking or in actions. Cindua Mato figures isa figure that always holds the mandate. That is why Dang Tuankubelieve in him to pick up his lover inNgiang River. If its not, where might Bundo Kanduang and Dang Tuanku want to appoint Cindua Mato as a messenger of the Pagaruyuang kingdom. As like his appointment to replace Bundo Kanduang as the king of Pagaruyuang (because Bundo Kanduang, Dang Tuanku, and Puti Bungsu are flying to the sky).

Besides having the similarities between Hang Tuah (in Hang Tuah saga) and Cindua Mato (in Cindua Mato tale), both of texts also have significant differences. The difference is evident from the aspect of the theme of the story and the character of both figures. The slander in Hang Tuah saga is addressed to a character named Hang Tuah, while the slander in Cindua Mato saga is addressed to Raja Alam. The embarrassment caused by the slander is certainly not the same between the mental disturbancesthat Hang Tuah felt as a palace soldier with the soul burden that is Dang Tuanku felt as Raja Alam. In addition, in Hang Tuah saga, Hang Tuah characters must have run away several times because all of those slander which directed to him and the king asked him to leave the palace. But in Cindua Mato saga, Dang Tuanku's character never escaped due to the slander that directed against him. He still remained in the palace.

Another difference is Hang Tuah (in hang Tuah saga) did not marry his girlfriend Tun Teja because his lover was finally declared herself as the king's wife. While the character Dang Tuanku (in Cindua Mato saga) finally succeeded in marrying her lover (Puti Bungsu) after her lover was successfully re-kidnapped from Imbang Jayo in the Ngiang Riverto Pagaruyung. Dang Tuanku and Puti Bungsu live happily until they fly to the sky.

Furthermore, Hang Tuah character had to kill his own colleague, Hang Jebat, because ordered by the king, due to his actions in making a commotion in the palace environment which madethe king very worried about. Although Hang Jebat is actually an old friend fromhis childhood, they both also triumph over the pirates in the South China Sea. They werecrush the riots that do the commotion in the palace together. He is a friend who always helped him in carrying out the duties in the king's palace. It did not happen to Cindua Mato figure (in the saga of Cindua Mato). Dang Tuanku as a friend of his childhood who he is always defended from any danger that might be happen. This evidenced is when he received a mandate from Bundo Kanduang and Basa Ampek Hall to attend the feast of Puti Bungsu with Imbang Jayo in Ngiang River. Dang Tuanku entrust the message, if it could be possible that his lover, Puti Bungsu, brought to Pagaruyuang. As a loyal friend, Cindua Mato carries out his friend's message. Cindua Mato madehis friend happy because he succeeded in marrying Puti Bungsu. It is remarkable local wisdom possessed by the Malay lands and Minang realm (Minangkabau). 


\section{CONCLUSION}

Based on the analysis and interpretation that has been done on the text of Hang Tuah and Cindua Mato then obtained the elements of similarities and differences that are owned by both of texts. From the aspect of equation, the equation that the two texts have is; (1) lifting the element of slander and shame element as the main theme. Hang Tuah character get slander from a palace guard named Patih Kerma Wijaya for several times so he also has to run away to save himself for several times. Also with Dang Tuanku character. Dang Tuanku getsslandered by Imbang Jayo that he suffered an acute illness that could not be healed so Puti Bungsu must accept Imbang Jayo's proposal, if she did not want to be single. The slander that Kerma Wijaya patronized against Hang Tuah made Hang Tuah embarrassed in front of the crowd. The same happened with Dang Tuanku. Imbang Jayo's slander made the environment of Pagaruyuang's palace ashamed so Cindua Mato was sent to take the responsibility of the slander caused by Imbang Jayo; (2) From the aspect of the figure, Hang Tuah and Cindua Mato is a figure who'sthe society believes as a brave character and has tremendous strength. Because of that, Hang Tuah succeeded in crushing the lanun, rebel, and riots in the palace. Cindua Mato, also, because of his courage and bravery, he succeeded in crushing the thieves in Tambun Tulang Hill, killing Imbang jayo who made all of those slanders, and Tiang Bungkuk (the very haunted father of Imbang Jayo) who wanted to kill him (Cindua Mato) for killing his son named Imbang Jayo; (3) From character aspect, Hang Tuah and Cindua Mato characters are very loyal figure to their king. According to Liaw Yock Fang (2011, p.442) the loyalty shown by the people and the palace guard shows the sovereignty and greatness of the Malay kings. With sovereignty it is expected that all of the people are afraid of and show their trully faithful and obedience to the kings; (4) From the aspect of social values, Hang Tuah and Cindua Mato figures are equally able to socialize well in the midst of their society. Both are the figures who always uphold the values of society so their presence in the middle of society is very acceptable; (5) From the aspects of cultural values, especially Malay and Minangkabau cultural values. Malay cultural values as embodied in Gurindam Dua Belas by the Malay master writer, Raja Ali Haji. Also with Minangkabau cultural values, as embodied in Malaypetatah-petitib custom, these two sagas are rich of cultural values.

From the differentiation aspect, the differences between the two texts are (1) Differences in the theme aspects which construct both text stories. The slander contained in the Hang Tuah saga is directly addressed to Hang Tuah characters, while the slander contained in the Cindua Mato saga is only directed to Dang Tuanku (the son of Pagaruyuang king). The shame is immediately felt by Hang Tuah while in the Cindua Mato saga the embarrassment directly to Dang Tuanku character and Bundo Kanduang as the king. Another difference is when Hang Tuah get slander, he immediately escape from the palace, while Dang Tuanku remain in the palace; (2) Hang Tuah (in hang Tuah saga) was not married to her lover named Tun Teja because her lover was finally declared herself to be the king's wife. While the character Dang Tuanku (in Cindua Mato saga) finally managed to marry his lover (Puti Bungsu) and Dang Tuanku and Puti Bungsulive a happy life. Thus it can be concluded that both the inner and outer text of the saga strongly supports the birth of a new interpretation. This is as suggested by Bakhtin (1986, p.104-107), Kristeva (1980, p.60), Barthes in Esten (1999, 14), Wolfgang Iser in Holub (1984, p.83), Riffatere (1978, p.1), Teeun (1991), and Junus (1981).

Thus, based on the results of analysis and interpretation on the similarities and differences of Hang Tuah and Cindua Mato figures, it can be concluded that Hang Tuah is a royal greatness of Malay land, while Cindua Mato is also a great figure from Minangkabau land. Both figures are brave and faithful to their king without any defect at all. Both texts are derived from the 
same literary genre, the old literature. With this similarity it can be said that the Malay and Minangkabau races have a close kinship. It is prove with his literary inventions. Although it has a little difference but the element of the similarity is more dominant in both of texts.

\section{REFERENCES}

Ahimsa-Putra, H.S. (2006). Strukturalisme Levi-Strauss Mitos dan Karya Sastra. Yogyakarta: Kepel Press

Bakhtin, M. (1986). Speech Genre and Other Late Essays. Austin: University of Texas Press

Culler, J. (1981). The Pursuit of Signs. London:RKP.

Dian Heri, S. (2010). "Hikayat Cindua Mato".

https://ceritarakyatindonesia.

wordpress.com / / / 02/24/cindua-mato

Eagleton, T. (1988. Teori Kesusastraan: Suatu Pengenalan. Kuala Lumpur: Dewan Bahasa dan Pustaka

Endraswara, S. (2011).Metodologi Penelitian Sastra: Epistemologi, Model, Teori, dan Aplikasi. Yogyakarta: CAPS.

Esten, M. (1999). Kajian Transformasi Budaya. Bandung: Angakasa

Fang, Liaw Yock. (2011). Sejarah Kesusastraan Melayu Klasik. Jakarta: Yayasan Pustaka Obor.

Fikyindra. (2015). "Kajian Strukturalisme dan Nilai-Nilai Pada Hikayat Hang Tuah Jilid I Karya Muhammad Haji Saleh". jurnal untan.ac.id/index.php/jpdpb/ / 2015

Frow, J. (1990). Intertextuality and Ontology.In M. Worton \& J. Still. (Eds.), Intertextuality: Theories and Practices (pp. 45-55). Manchester: Manchester University Press.

Holub, R.C. (1984). Reception Theory. New York:Methuen

Junus, U. (1981). Mitos dan Komunikasi. Jakarta: Sinar Harapan

Kristeva, J. (1980). Desire in Language: $A$ Semiotics Approach to Literature and Art. London: Blackwell Publisher Inc.
Nurgiyantoro, B., \& Effendi, A. (2017).Reactualisation of Puppet Characters in Modern Indonesian Fictions of the 21st Century. Malaysia: Jurnal $3 L$ UKM

Ratna, N.K. (2011). Teori, metode, dan Teknik Penelitian Sastra. Yogyakarta: Pustaka Pelajar

Riffatere, M. (1978). Semiotics of Poetry. Blomington: Indiana University Press.

Ruaidah, R. (2017). Ideologi Feminisme dalam Kaba Cindua Mato. Kafaab: Journal of Gender Studies, 7(1), 15-25.

Scholes, R. (1974). Structuralism in Literature: An Introduction. New Haven Yale University Press

Taum, Y.Y. (1997). Pengantar Teori Sastra. Bogor: Penerbit Nusa Indah

Teeuw, A. (1991). Membaca dan Menilai Sastra: Jakarta: PT Gramedia Pustaka Utama.

Wulandari, Y. (2016). Perempuan minang dalam kaba cindua mato karya syamsuddin st. Rajo endah dan memang jodoh karya marah rusli. Jurnal Penelitian Humaniora, 16(1), February 2016. doi: https://doi.org/10.23917/hum aniora.v16i1.1520

Yullia, S. (2014). "Hikayat Hang Tuah Dan Kaba Laksamana Hang Tuab: Kajian Hipogramatik". scholar.unand.ac.id/9255/

Zaimar, O.F.S.K.S. (1990). Menelusuri Makna Ziarah Karya Iwan Simatupang. Disertasi Universitas Indonesia (Diterbitkan dalam Seri ILDEP) 